\title{
Spinal Cord Neuronal Precursors Generate Multiple Neuronal Phenotypes in Culture
}

\author{
Anjali J. Kalyani, ${ }^{2}$ David Piper, ${ }^{1}$ Tahmina Mujtaba, ${ }^{2}$ Mary T. Lucero, ${ }^{1}$ and Mahendra S. Rao ${ }^{2}$ \\ ${ }^{1}$ Department of Physiology, University of Utah, Salt Lake City, Utah 84132, and '2Department of Neurobiology and \\ Anatomy, University of Utah School of Medicine, Salt Lake City, Utah 84132
}

\begin{abstract}
Neuronal restricted precursors (NRPs) (Mayer-Proschel et al., 1997) can generate multiple neurotransmitter phenotypes during maturation in culture. Undifferentiated E-NCAM ${ }^{+}$(embryonic neural cell adhesion molecule) immunoreactive NRPs are mitotically active and electrically immature, and they express only a subset of neuronal markers. Fully mature cells are postmitotic, process-bearing cells that are neurofilament-M and synaptophysin immunoreactive, and they synthesize and respond to different subsets of neurotransmitter molecules. Mature neurons that synthesize and respond to glycine, glutamate, GABA, dopamine, and acetylcholine can be identified by immunocytochemistry, RT-PCR, and calcium imaging in mass cultures. Individual NRPs also generate heterogeneous prog-
\end{abstract}

Initially homogeneous neuroepithelial (NEP) stem cells (Kalyani et al., 1997) of the embryonic spinal cord are patterned in vivo to generate mature neurons, oligodendrocytes, and astrocytes in a characteristic spatial and temporal profile (Hamburger, 1948; Hirano and Goldman, 1988; Nornes and Das, 1974; Phelps et al., 1988). NEP cell differentiation, both in vitro and in vivo, likely involves a process of restriction in developmental potential (for review, see McKay, 1997; Stemple and Mahanthappa, 1997). In vitro, pluripotent NEP cells generate restricted precursor cells, termed neuronal restricted precursors (NRPs) (Mayer-Proschel et al., 1997), and glial restricted precursors (GRPs) (Rao et al., 1998), which subsequently develop into fully differentiated neuron and glial cells, respectively. Similar cells are present in vivo (Mayer-Proschel et al., 1997; Rao and Mayer-Proschel, 1997). In vivo neurogenesis precedes and overlaps differentiation of oligodendrocytes and astrocytes (Abney et al., 1981; Frederiksen and McKay, 1988; Hirano and Goldman, 1988; Miller et al., 1985), and is modulated by multiple environmental signals.

Immature neuronal cells undergo additional changes to develop into functional neurons that differ in morphology, receptor profile, and neurotransmitter synthesizing abilities (Phelps et al.,

Received April 1, 1998; revised July 20, 1998; accepted July 21, 1998.

This work was supported by the Muscular Dystrophy Association, the March of Dimes, and a National Institutes of Health first award to M.S.R. A.J.K. was supported by a National Institutes of Health Multidisciplinary Basic Cancer Research Training Grant. D.P. and M.T.L. were supported by a National Institutes of Health RO1 grant. We thank Drs. M. Vetter, S. A. Scott, and M. Condic for their critical reviews of this manuscript. We thank the Developmental Studies Hybridoma Bank (DSHB) for the antibodies used. DSHB is maintained by the University of Iowa under contract NO1-HD-7-3263 from National Institutes of Health (NICHD).

M.S.R. gratefully acknowledges the constant support of Dr. S. Rao through all phases of this project.

Correspondence should be addressed to Dr. Mahendra Rao, Department of Neurobiology and Anatomy, University of Utah School of Medicine, 50 N. Medical Drive, Salt Lake City, Utah 84132.

Copyright (C) 1998 Society for Neuroscience $\quad 0270-6474 / 98 / 187856-13 \$ 05.00 / 0$ eny as assessed by neurotransmitter response and synthesis, demonstrating the multipotent nature of the precursor cells.

Differentiation can be modulated by sonic hedgehog (Shh) and bone morphogenetic protein (BMP)-2/4 molecules. Shh acts as a mitogen and inhibits differentiation (including cholinergic differentiation). BMP-2 and BMP-4, in contrast, inhibit cell division and promote differentiation (including cholinergic differentiation). Thus, a single neuronal precursor cell can differentiate into multiple classes of neurons, and this differentiation can be modulated by environmental signals.

Key words: E-NCAM; spinal cord development; neuroblasts; stem cells; Shh; BMP

1988, 1990; Ray and Gage, 1994; Richards et al., 1995). These properties are thought to be acquired in a sequential manner during the course of development. Likewise, electrical properties seem to be acquired sequentially (Desarmenien et al., 1993; Walton et al., 1993). For example, functional sodium channels appear before either GABA or glutamate receptors, and spinal neurons therefore show spontaneous electrical activity before any response to GABA or glutamate. Furthermore, the initial GABA responses are depolarizing, and thus they differ from adult inhibitory responses; reversal occurs postnatally (Ben-Ari et al., 1989; Zhang et al., 1990). The acquisition of electrical properties has not been correlated with morphological markers of maturation or the ability to synthesize neurotransmitters.

The acquisition of mature neuronal properties is likely modulated by environmental signals (Cattaneo and McKay, 1990; Echelard et al., 1993; Roelink et al., 1994; Liem et al., 1995, 1997; Muhr et al., 1997; Williams et al., 1997). Two molecules that modulate early neuronal differentiation are bone morphogenetic protein (BMP) and sonic hedgehog (Shh). Shh, a protein secreted by the notochord and floor plate, regulates the induction of motoneurons and some classes of ventral interneurons (Yamada et al., 1993; Roelink et al., 1994). BMP proteins are present dorsally and appear to mediate the generation of dorsal phenotypes (Liem et al., 1995, 1997; Mujtaba et al., 1998). The specific effects of Shh and BMP on isolated neural cells at different developmental stages, and the mechanisms by which they act (proliferation, survival, or differentiation), remain to be determined.

Here we have examined the acquisition of phenotypic properties of NRP cells by comparing immunological and physiological properties of cultured immature neuronal precursors and the mature neurons that differentiate from them. We show that individual NRP cells can differentiate into multiple types of neurons 
and that differentiation occurs via a characteristic pattern of development. In addition, we show that differentiation is modulated by Shh and BMP.

\section{MATERIALS AND METHODS}

\section{Substrate preparation}

Fibronectin (Sigma, St. Louis, MO) was diluted to a concentration of 20 $\mu \mathrm{g} / \mathrm{ml}$ in Tissue Culture $\mathrm{H}_{2} 0$ (Sigma). Fibronectin solution was applied to tissue culture dishes for a minimum of $4 \mathrm{hr}$. Laminin (Biomedical Technologies, Stoughton, MA), used at a concentration of $20 \mu \mathrm{g} / \mathrm{ml}$, was dissolved in Dulbecco's PBS (DPBS) (Life Technologies/BRL, Gaithersburg, MD). To prepare fibronectin-laminin double-coated dishes, lami$\operatorname{nin}(20 \mu \mathrm{g} / \mathrm{ml})$ was applied to fibronectin-coated dishes, and plates were incubated overnight. Excess laminin was withdrawn, and the plates were rinsed with NEP medium before cells were plated.

\section{Immunopanning of E-NCAM${ }^{+}$cells}

Sprague Dawley rat embryos were removed at embryonic day 13.5 (E13.5) and placed in a Petri dish containing DPBS (Life Technologies/ BRL). Spinal cords were mechanically dissected from the surrounding connective tissue with sharpened No. 5 forceps. Isolated spinal cords were incubated in $0.05 \%$ trypsin solution for $30 \mathrm{~min}$. The trypsin solution was replaced with NEP medium. The segments were gently triturated with a Pasteur pipette to dissociate cells. E-NCAM ${ }^{+}$cells were purified from dissociated cells using a specific antibody-capture assay (Wysocki and Sato, 1978) with minor modifications. In brief, the dissociated cells in suspension were plated on an NCAM antibody (5A5, Developmental Studies Hybridoma Bank)-coated dish to allow binding of all E-NCAM ${ }^{+}$ cells to the plate. NCAM antibody-coated dishes were prepared by sequentially coating tissue culture dishes with an unlabeled anti-mouse IgM antibody $(10 \mu \mathrm{g} / \mathrm{ml})$ overnight, rinsing dishes with DPBS, followed by coating with 5 A5 hybridoma supernatant for $1-3 \mathrm{hr}$ at room temperature. Cells were allowed to bind to the plate for $1 \mathrm{hr}$ at room temperature. Unbound cells were removed, and the plate was rinsed eight times with DPBS. Bound cells were mechanically scraped off and plated on fibronectin-laminin-coated dishes in $1 \mathrm{ml}$ of NEP medium in either mass (5000 cells/dish) or clonal culture (100 cells/dish). Growth factors were added every other day. In all cases, an aliquot of cells was analyzed the next day to determine the efficiency of the immunopanning. In general,
$>90 \%$ of the bound cells expressed detectable NCAM immunoreactivity. Cell populations that did not were repanned or discarded.

\section{NRP cell cultures}

Immunopanned E-NCAM ${ }^{+}$cells were plated in culture dishes (Corning, Corning, NY) coated with fibronectin-laminin at a dilution of 5000 cells/dish. Cells were maintained at $37^{\circ} \mathrm{C}$ in $5 \% \mathrm{CO}_{2} / 95 \%$ air. The basal medium (NEP medium) used in all experiments was a chemically defined medium as described previously (Mayer-Proschel et al., 1997). The medium consisted of DMEM-F12 (Life Technologies/BRL) supplemented with additives described by Bottenstein and Sato (1979) and basic fibroblast growth factor (bFGF) $(20 \mathrm{ng} / \mathrm{ml})$.

\section{Clonal cultures of NRP cells}

Immunopanned cells were plated in culture dishes (Corning) coated with fibronectin-laminin at a dilution of 100 cells/dish. Approximately $10-$ $20 \%$ of single cells died within $24 \mathrm{hr}$. The remaining single cells were allowed to proliferate until large enough to assay (between 7 and $10 \mathrm{~d}$ ). Clones were isolated using glass cloning rings. Greased rings were placed around a selected, well isolated clone, and cells were dissociated from the substrate using trypsin-EDTA. Dissociated cells were aspirated, and the trypsin-EDTA was neutralized with excess medium. For RT-PCR analysis, clonal cells were then centrifuged and harvested for RNA isolation. For calcium imaging experiments, clones were replated on poly-lysine/ laminin-coated glass coverslips. Cells were imaged $24-48 \mathrm{hr}$ after replating to ensure that they had recovered from the replating process. For immunocytochemistry, cells were replated on poly-lysine/laminin-coated dishes and allowed to settle and extend processes before being analyzed. In all cases, clones were grown in NEP medium as described above [also see Kalyani et al. (1997)], supplemented with neurotrophin-3 $(10 \mathrm{ng} / \mathrm{ml})$.

\section{Differentiation of NRP cells and Shh and BMP treatment}

Neuronal differentiation of cultured NRP cells was induced by plating on poly-lysine/laminin-coated dishes (poly-lysine at $20 \mu \mathrm{g} / \mathrm{ml}$ in DPBS; Sigma), and reducing FGF concentration with the addition of RA (1 $\mu \mathrm{M})$. In some experiments, neuronal differentiation was induced by the addition of BMP-2 or BMP-4 at $10 \mathrm{ng} / \mathrm{ml}$. The effects of Shh and BMP were assessed by supplementing NEP medium with Shh at doses of 1-100 $\mathrm{ng} / \mathrm{ml}$, or BMP-2 or BMP-4 at $10 \mathrm{ng} / \mathrm{ml}$. To assess the effect of Shh on mitosis, we withdrew FGF from cultures, rinsed them with FGF-free

\begin{tabular}{|c|c|c|}
\hline Gene & Product size (bp) & Primers (sense, antisense) \\
\hline \multirow[t]{2}{*}{ p75 } & 329 & 5'-GCA CAT ACT CAG ACG AAG CCA-3' \\
\hline & & 5'-AGC AGC CAA GAT GGA GCA ATA GAC-3' \\
\hline \multirow[t]{2}{*}{ ChAT } & 377 & 5'-CTG AAT ACT GGC TGA ATG ACA TG-3' \\
\hline & & 5'-AAA TTA ATG ACA ACA TCC AAG AC-3' \\
\hline \multirow[t]{2}{*}{ Isl-1 } & 350 & 5'-GCA GCA TAG GCTTCA GCA AG-3' \\
\hline & & 5'-GTA GCA GGT CCG CAA GGT G-3' \\
\hline \multirow[t]{2}{*}{$\mathrm{GAD}_{65}$} & 327 & 5'-GAA TCT TTT CTC CTG GTG GTG-3' \\
\hline & & 5'-GAT CAA AAG CCC CGT ACA CAG-3' \\
\hline \multirow[t]{2}{*}{ Calbindin 28} & 276 & 5'-GCA GAA TCC CAC CTG CAG-3' \\
\hline & & 5'-GTT GCT GGC ATC GAA AGA G-3' \\
\hline \multirow[t]{2}{*}{ Glutaminase } & 560 & 5'-GCA CAG ACA TGG TTG GGA TAC TAG-3' \\
\hline & & 5'-GCA GGG CTG TTC TGG AGT CG-3' \\
\hline \multirow[t]{2}{*}{ Smoothened } & 467 & 5'-GGA CAG ACA ACC CCA AGA GC-3' \\
\hline & & 5'-CCG AGA GAG GCT GGT AAG TGG-3' \\
\hline \multirow[t]{2}{*}{ Patched } & 1297 & 5'-CAA TGG CTA CCC CTT CCT GTT CTG-3' \\
\hline & & 5'-CGG CCT CTC CTC ACA TTC CAC-3' \\
\hline \multirow[t]{2}{*}{ glyRa2 } & 330 & 5'-CAG AGT TCA GGT TCC AGG G-3' \\
\hline & & 5'-TCC ACA AAC TTC TTC TTG ATA G-3' \\
\hline \multirow[t]{2}{*}{$\mathrm{GABA}_{\mathrm{A}}-\mathrm{R}$} & 589 & 5'-TGG AC(TC) CC(AT) GA(TC) AC(ACT)TT(TC) TT-3' \\
\hline & & 5'-GC(AGTC) AT(GA) AAC CA(GA)TCC ATG GC-3' \\
\hline \multirow[t]{2}{*}{ Cyclophilin } & 302 & 5'-CCA CCG TGT TCT TCG ACA TC-3' \\
\hline & & 5'-GGT CCA GCA TTT GCC ATG G-3' \\
\hline
\end{tabular}


medium, and added Shh $(100 \mathrm{ng} / \mathrm{ml})$ in the presence of the survival agent NT-3. This was required, because quantifying an increase in mitosis in the presence of saturating concentrations of FGF was technically difficult. For all other experiments, the effects of Shh with or without FGF were identical. BMP-2, -4 , and -7 were obtained from Genetics Institute (Cambridge, MA), and Shh (N-terminal form) was obtained from Ontogeny Inc.

\section{Gene detection by RT-PCR}

$R N A$ isolation. Total RNA was isolated from cells or whole tissues by a modification of the guanidine isothiocyanate-phenol-chloroform extraction method (Trizol, Life Technologies/BRL).

cDNA synthesis. cDNA was synthesized using 1-5 $\mu \mathrm{g}$ of total RNA in a $20 \mu \mathrm{l}$ reaction. Superscript II (Life Technologies/BRL), a modified Maloney murine leukemia virus reverse transcriptase, and oligo-d $\mathrm{T}_{12-18}$ primers were used, and the Life Technologies/BRL protocol was followed.

$P C R$. Aliquots of cDNA, equivalent to one-twentieth of the above reaction, were used in a $50 \mu \mathrm{l}$ reaction volume. PCR amplification was performed using ELongase polymerase (Life Technologies/BRL). Primer sequences used for PCR amplification are shown in Table 1. In general, the reactions were run for 35 cycles, unless stated otherwise, and a $10 \mathrm{~min}$ incubation at $72^{\circ}$ was added at the end to ensure complete extension. In the case of GABA receptors, co-amplification of $\mathrm{GABA}_{\mathrm{A}} \mathrm{R}$ subunits was performed using degenerate primers for the $\alpha$-subfamily (subunits 1-6) (Berger et al., 1998). The PCR products were purified using the Advantage PCR-Pure Kit (Clontech, Palo Alto, CA) and sequenced to confirm their identities. All PCR results reported were reproduced reliably using cDNA collected from five to seven independent experiments unless stated otherwise.

Quantification of ptc relative levels. The same amount of cDNA was used in PCR reactions using primers for cyclophilin and ptc. PCR with cyclophilin primers was performed for 23 cycles, and PCR with ptc primers was preformed for 35 cycles; amplification was within the linear range. The ratio of cyclophilin to ptc within a sample was determined by scintillation radiometry (ImageQuant, Molecular Dynamics, Sunnyvale, CA). This ratio was then compared across samples within each experiment, and the SEM was determined.

\section{Immunocytochemistry}

Staining procedures were as described previously (Rao and MayerProschel, 1997). Staining for the cell surface markers p75 and E-NCAM was performed in cultures of living cells. To stain cells with antibodies against internal antigens, cultures were fixed with $2-4 \%$ formaldehyde for $30 \mathrm{~min}$ at room temperature. In general, dishes were incubated with the primary antibody for $1 \mathrm{hr}$ followed by incubation with an appropriate secondary antibody for 1 additional hr. The peroxidase reaction for HRP-conjugated secondaries was performed as described previously (Rao et al., 1992). Double-labeling experiments were performed by simultaneously incubating cells in appropriate combinations of primary antibodies followed by noncross-reactive secondary antibodies. Diamino-bisbenzimide (DAPI) (Signal) histochemistry was performed as described previously (Kalyani et al., 1997). DAPI staining was generally performed after all other antibody staining had been completed.

p75, E-NCAM, and nestin monoclonal antibodies (Lendahl et al., 1990; Dahlstrand et al., 1995) were hybridoma supernatants obtained from the Developmental Studies Hybridoma Bank (DSHB). $\beta$-III tubulin antibody, which stains neurons, was obtained from Sigma. An anti-nestin polyclonal antibody used in some double-labeling experiments was the kind gift of Dr. Keith Cauley (Signal Pharmaceuticals). Antibodies to choline acetyltransferase (ChAT), tyrosine hydroxylase (TH), and glutamic acid decarboxylase (GAD) were obtained from Chemicon (Temecula, CA) and used at dilutions recommended in the enclosed protocols. Antibodies to glutamate and glycine were obtained from Signature Immunologicals and used according to manufacturer's recommendations. 5-Bromodeoxyuridine (BRDU, Sigma) was used to determine the number of dividing cells. Mouse and rat monoclonal anti-BRDU antibodies were obtained from Boehringer Mannheim (Indianapolis, IN). All secondary monoclonal antibodies were purchased from either Jackson ImmunoResearch (West Grove, PA) or Southern Biotechnology (Birmingham, AL).

\section{Neutralizing antibody experiments}

E-NCAM ${ }^{+}$-immunopanned cells were plated on fibronectin-laminincoated dishes in basal medium supplemented with NT-3. Four hours after plating, cells were treated with Shh $(100 \mathrm{ng} / \mathrm{ml})$, neutralizing anti-Shh hybridoma supplement $(50 \mu \mathrm{l} / \mathrm{ml})$, or control (anti-A2B5) hybridoma supernatant. Cells were grown in combinations of Shh and antibody as described in Results for a period of $48 \mathrm{hr}$. Cultures were pulsed with BRDU in the last $3 \mathrm{hr}$ of culture, fixed, and processed for BRDU incorporation and DAPI histochemistry as previously described. BRDU-incorporating cells were counted in five randomly chosen fields, and the number of dividing cells was expressed as a percentage of the DAPI-labeled nuclei in the same fields. All experiments were performed in duplicate, and the experiments were repeated at least twice. Results are presented as the mean of two experiments \pm SEM.

\section{Intracellular calcium measurements}

$\mathrm{Ca}^{2+}$ imaging experiments were performed on both mass and clonal cultures of E-NCAM ${ }^{+}$cells obtained as described above. Cells were loaded with $5 \mu \mathrm{M}$ fura-2 AM (Grynkiewicz et al., 1985) plus pluronic F127 $(80 \mu \mathrm{g} / \mathrm{ml})$ in rat Ringers's solution (RR) at $23^{\circ} \mathrm{C}$ in the dark for 20 min followed by three washes in RR and a $30 \mathrm{~min}$ de-esterification. Relative changes in intracellular $\left[\mathrm{Ca}^{2+}\right]$ were measured from the background-corrected ratio of fluorescence intensity by excitation at $340 / 380 \mathrm{~nm}$. Response was defined as a minimum rise of $10 \%$ of the ratioed baseline value. A Zeiss-Attofluor imaging system and software (Atto Instruments, Rockville, MD) were used to acquire and analyze the data. Data points were sampled at $1 \mathrm{~Hz}$. Neurotransmitters were made in $\mathrm{RR}$ and delivered by bath exchange using a small volume loop injector $(200 \mu \mathrm{l})$. RR consisted of (in mM): $140 \mathrm{NaCl}, 3 \mathrm{KCl}, 1 \mathrm{MgCl}_{2}, 2 \mathrm{CaCl}_{2}$, 10 HEPES, and 10 glucose. Ascorbic acid $(500 \mu \mathrm{M})$ was added to dopamine solutions to prevent oxidation. Control application of $500 \mu \mathrm{M}$ ascorbic acid had no effect (data not shown). The $\mathrm{pH}$ of all solutions was adjusted to 7.4 with $\mathrm{NaOH}$. $\mathrm{K}^{+} \mathrm{RR}(50 \mathrm{~mm})$ was made by substituting equimolar $\mathrm{K}^{+}$for $\mathrm{Na}^{+}$in the normal RR.

\section{RESULTS}

\section{$\mathrm{E}-\mathrm{NCAM}^{+}$cells mature in culture}

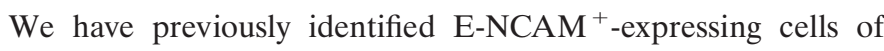
E13.5 neural tube as neuronal restricted precursors (MayerProschel et al., 1997). Immunocytochemical studies have shown that virtually $100 \%$ of the E-NCAM ${ }^{+}$cells dissociated at this time express the early neuronal marker microtubule-associated protein kinase-2 (MAP-2 kinase), $\sim 50 \%$ express $\beta$ III-tubulin, but only $\sim 10 \%$ express the neuronal marker NF-M when cultured in nondifferentiation promoting medium that includes fibroblast growth factor (FGF) as a survival agent (Mayer-Proschel et al., 1997). After the removal of FGF and the addition of retinoic acid (RA), E13.5 E-NCAM ${ }^{+}$cells exit the mitotic cycle, increase in soma size, and begin to extend extensive processes.

To determine more accurately the process of in vitro maturation, we performed several experiments that were repeated between six and nine times with similar and reproducible results. The proportion of dividing cells was compared in acutely dissociated and differentiated cells using BRDU incorporation. Approximately $70 \%$ of acutely dissociated cells incorporate BRDU (Fig. $1 A$ ), whereas after $10 \mathrm{~d}$ in culture (in differentiationpromoting medium), few or no cells incorporate BRDU and therefore had stopped dividing (Fig. $1 B$ ). Next, we examined the acquisition of NF-M, which is not expressed by the majority $(\sim 90 \%)$ of E13.5 E-NCAM ${ }^{+}$NRP cells (Mayer-Proschel et al., 1997), by immunocytochemistry. Cells were double-labeled with NCAM (Fig. $1 C, D$ ) and NF-M (Fig. $1 c, d$ ). Figure $1 c, d$ shows that very few acutely dissociated cells express NF-M, whereas nearly all differentiated cells express the protein. Similarly, synaptophysin, a protein specifically associated with synaptic vesicles and functional synapses (for review, see Sudhof, 1995), is expressed by differentiated (Fig. $1 f$ ) but not acutely dissociated E-NCAM ${ }^{+}$ cells (Fig. 1e). Although synaptophysin protein expression is associated with synaptic vesicles, early expression (as seen in Fig. 1f) can be detected in the cell bodies and throughout the lengths 


\section{ACUTELY DISSOCI ATED}
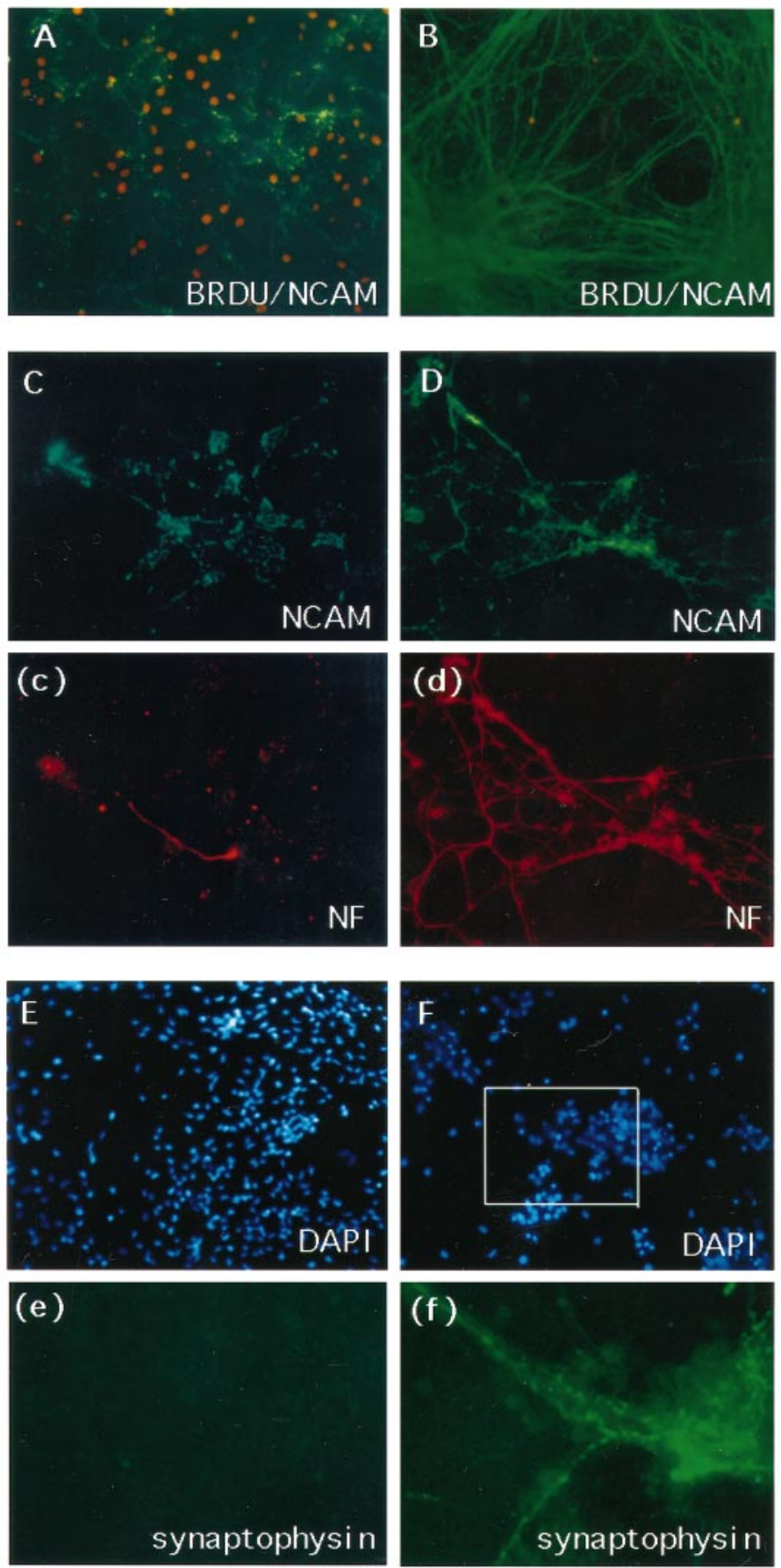

Figure 1. Differentiated E-NCAM ${ }^{+}$cells can be distinguished from acutely dissociated NRP cells. E-NCAM ${ }^{+}$cells were isolated by immunopanning, plated in $35 \mathrm{~mm}$ dishes, and allowed to grow for $24 \mathrm{hr}$ (acutely dissociated) or for $10 \mathrm{~d}$ (differentiated). Cultured cells were then analyzed for cell division, E-NCAM expression, NF-M expression, and synaptophysin expression. Most acutely dissociated E-NCAM ${ }^{+}$cells (green, $A$ ) incorporate BRDU $(\mathrm{red}, A)$. In contrast, few differentiated $\mathrm{E}^{-N C A M}{ }^{+}$ cells (green, $B$ ) are BRDU immunoreactive (red, $B$ ). Most acutely dissociated E-NCAM ${ }^{+}$cells (green, $C$ ) were not NF-M immunoreactive (red,

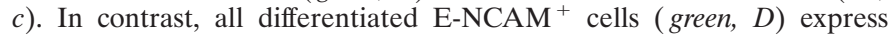
NF-M $(r e d, d)$. In addition, acutely dissociated cells do not express synaptophysin as assessed by synaptophysin staining ( green) and DAPI (compare $e$ and $E$, respectively). A subset of differentiated $\mathrm{E}^{-\mathrm{NCAM}^{+}}$ of the processes where it is initially expressed during early neurogenesis (Grabs et al., 1994; Fujita et al., 1996). Corresponding nuclear DAPI staining is shown in Figure $1 E, F$ to demonstrate the location of the cell bodies. These results suggest that if NRP cells are induced to differentiate by RA and the removal of mitogen, they acquire many morphological and immunological properties of mature neurons.

\section{Cultured E-NCAM ${ }^{+}$cells can synthesize and respond to multiple neurotransmitters}

We have shown previously that NRP cells can differentiate into postmitotic neurons but not into oligodendrocytes or astrocytes (Mayer-Proschel et al., 1997). To determine whether NRPs can differentiate into all of the major neuronal phenotypes present in the spinal cord, or whether they are more limited in their differentiation potential, we examined the expression of neurotransmitter synthesizing enzymes and cell type-specific markers for mature neurons after inducing NRPs to differentiate.

E-NCAM ${ }^{+}$cells from E13.5 rat neural tube were isolated by immunopanning and cultured in differentiation-promoting medium (see Materials and Methods). After $10 \mathrm{~d}$ in culture, we analyzed the synthesis of the neurotransmitters acetylcholine (ACh), GABA, and glutamate (as assessed by the expression of their synthesizing enzymes) using RT-PCR (Table 1). In addition, we examined the expression of p75 (Yan and Johnson, 1988) and Islet-1 (Isl-1) (Tsuchida et al., 1994), which are characteristic of motoneurons in the spinal cord, and calbindin, which is often co-expressed with GABA (Batini, 1990). As shown in Figure 2, Panel 1, all of these were present in differentiated cells (labeled $D$ in Panel 1). In contrast, none of these markers of neurotransmitter phenotypes could be detected from cells that were examined within $24 \mathrm{hr}$ of isolation (termed "acutely dissociated"; labeled $A D$ in Panel 1), although we could readily detect the housekeeping gene cyclophilin from both cell populations (as shown in Panel 1). Thus, our data show that neuron-restricted precursor cells mature in culture and that NCAM expression and neuronal fate determination precede neurotransmitter synthesis.

We also examined the expression of neurotransmitters or their synthesizing enzymes by immunocytochemistry to determine whether all cells or only subsets of differentiated cells express these markers. Cells were grown in culture for $10 \mathrm{~d}$ and allowed to differentiate and then were fixed and processed by immunocytochemistry to detect expression of ChAT (Fig. 2, Panel 2, B), GAD $(D)$, TH $(F)$, glycine $(H)$, and glutamate $(J)$. Virtually $100 \%$ of the differentiated cells expressed detectable glutamate levels, and this percentage did not vary significantly from experiment to experiment $(n=6)$. A smaller percentage expressed glycine and GAD. Percentages varied between experiments from 10 to $50 \%$. The percentages of $\mathrm{ChAT}$ and $\mathrm{TH}^{+}$cells ranged between 1 and $5 \%$ (these cells usually appeared in clumps, rather than being equally distributed throughout the population, as seen in Fig. 2, Panel 2, B,F). The use of nonspecific differentiationpromoting factors resulted in considerable variability in the numbers of any given phenotype generated (except glutamate) from experiment to experiment ( $n=6$ independent experiments). However, although the exact percentages varied, heterogeneity of

cells, however, have begun to express detectable levels of synaptophysin (compare $f$ and $F$, respectively; $f$ is a magnification of the area within the white box in $F$ ). Thus, acutely dissociated E-NCAM ${ }^{+}$cells are immature, dividing cells that mature in culture. Objective magnification, 20×. 
Table 2. Acutely dissociated and differentiated E-NCAM ${ }^{+}$cells differ in their properties

\begin{tabular}{|c|c|c|}
\hline & Acutely dissociated & Differentiated \\
\hline Mitotic status & Mitotic & Postmitotic \\
\hline Cell size & Comparatively smaller & Comparatively larger \\
\hline Process outgrowth & Little or none & Extensive \\
\hline \multirow[t]{6}{*}{ Neuronal markers } & NCAM & NCAM \\
\hline & $\beta$ III-tubulin & $\beta$ III-tubulin \\
\hline & MAP-2 kinase & MAP-2 kinase \\
\hline & Nestin & NF-M \\
\hline & & Synaptophysin \\
\hline & & Peripherin \\
\hline \multirow{8}{*}{$\begin{array}{l}\text { Neurotransmitters, neurotransmitter synthetic } \\
\text { enzymes, or other phenotype-specific markers }\end{array}$} & None, except for a small amount of glutamate & Glutamate \\
\hline & immunoreactivity & Glycine \\
\hline & & Glutaminase \\
\hline & & Glutamic acid decarboxylase \\
\hline & & Choline acetyltransferase \\
\hline & & Islet-1 \\
\hline & & $\mathrm{p} 75$ \\
\hline & & Calbindin \\
\hline Response to neurotransmitters & Weak and in a small subset of cells & Robust and in virtually all cells \\
\hline Depolarizing response to GABA and glycine & $\begin{array}{l}\text { Numerous cells with depolarizing responses } \\
\text { detected }\end{array}$ & $\begin{array}{l}\text { Few or no cells with depolarizing } \\
\text { responses detected }\end{array}$ \\
\hline
\end{tabular}

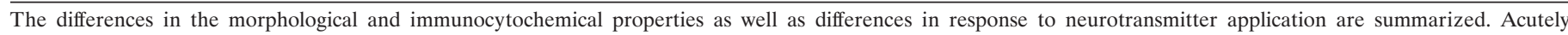

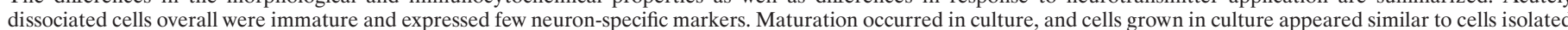

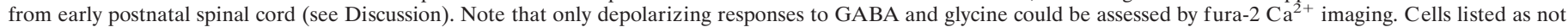
responding may have had hyperpolarizing responses.

phenotypes did not, and in all cases significant numbers of all phenotypes were detected. Also, because virtually $100 \%$ of the cells synthesize glutamate, it is likely that at least some cells synthesize more than one neurotransmitter. Nevertheless, these results clearly demonstrate that during differentiation, E-NCAM ${ }^{+}$ cells are capable of maturing into a heterogeneous population with respect to their neurotransmitter phenotype.

In contrast to the results obtained with differentiated cells, neither ChAT, GAD, TH, nor glycine could be detected in acutely dissociated cells. We did detect glutamate in a small subset of cells $(<10 \%$; data not shown) from each experiment $(n=6)$. We were unable, however, to detect glutaminase in these cells by RT-PCR (Fig. 2, Panel 1), which may suggest that glutamate is being taken up by these cells from the medium.

Another important characteristic of mature neurons is their ability to respond to multiple neurotransmitters by expressing appropriate neurotransmitter receptors on their surface. To examine the ability of differentiated $\mathrm{E}_{-} \mathrm{NCAM}^{+}$cells to respond to glutamate, glycine, dopamine, and acetylcholine, we used fura-2 $\mathrm{Ca}^{2+}$ imaging techniques. E13.5 E-NCAM ${ }^{+}$cells were grown in culture for $10 \mathrm{~d}$ and allowed to differentiate. They were then loaded with fura-2 (see Materials and Methods), and the depolarizing response to neurotransmitter application was monitored. Figure $3 A$ shows a bar graph of the number of cells (sum of cells from three independent experiments) responding to application of the indicated neurotransmitter on acutely dissociated and differentiated cells. In general, the number of cells responding to neurotransmitters and the amplitude of the neurotransmitterinduced $\mathrm{Ca}^{2+}$ responses increased in the differentiated cells. The most striking example was dopamine, where only $10 \%$ of acutely dissociated cells responded to $500 \mu \mathrm{M}$ dopamine with increases in internal $\mathrm{Ca}^{2+}$ compared with $76 \%$ of differentiated cells, a net increase of $66 \%$. Similar but less striking changes in the number of cells responding were seen for other excitatory neurotransmit- ters (Fig. 3A). The exceptions to this trend were the $\mathrm{Ca}^{2+}$ responses to GABA and glycine. Interestingly, $47 \%$ of the acutely dissociated cells responded to GABA compared with only $8 \%$ of the differentiated cells. Similarly, $\mathrm{Ca}^{2+}$ flux in response to glycine decreased from $20 \%$ in the acutely dissociated cells to $0 \%$ in the differentiated cells. To rule out the possibility that the cells were downregulating their receptors for these transmitters as they matured, we checked for the expression of $\mathrm{GABA}_{\mathrm{A}}-\alpha 1-6$ receptor subunits (Berger et al., 1998) and GlyR- $\alpha 2$, the predominant embryonic glycine receptor subunit expressed in neurons throughout the CNS (Heck et al., 1997). Both of these were readily detected by RT-PCR from cDNA of mature $\mathrm{NCAM}^{+}$ cells (data not shown). Therefore, the change in the inhibitory neurotransmitter profile probably reflects the decrease in internal $\mathrm{Cl}^{-}$concentration with maturation that accounts for the shift from depolarizing to hyperpolarizing GABA and glycine responses (Wu et al., 1992).

Representative plots of ratioed $\left(I_{340} / I_{380}\right) \mathrm{Ca}^{2+}$ responses over time from an acutely dissociated and differentiated cell are shown in Figure 3, $B$ and $C$, respectively. Figure $3 D$ shows images of the cells from which the data were taken; the cell represented in the plot is indicated by a letter in the image. The acutely dissociated cell responded to GABA and glutamate, whereas the differentiated cell from the same embryo responded to dopamine, glutamate, and acetylcholine but not to GABA or glycine. Comparison of $\mathrm{Ca}^{2+}$ responses to the various transmitters in adjacent cells reveals that there is heterogeneity in the response profiles among cells, indicating that not only are the E-NCAM ${ }^{+}$cells heterogeneous in their ability to synthesize neurotransmitters, they are also selective in terms of transmitter receptor expression. In addition to neurotransmitters, elevated $\mathrm{K}^{+}$in $\mathrm{RR}(50 \mathrm{mM} \mathrm{K}$ $\mathrm{RR})$ was applied to depolarize the cells and allow $\mathrm{Ca}^{2+}$ entry through voltage-gated channels. In acutely dissociated cells, $49 \%$ responded to $50 \mathrm{mM} \mathrm{K}^{+} \mathrm{RR}$ compared with $85 \%$ of differentiated 


\section{Panel 1}

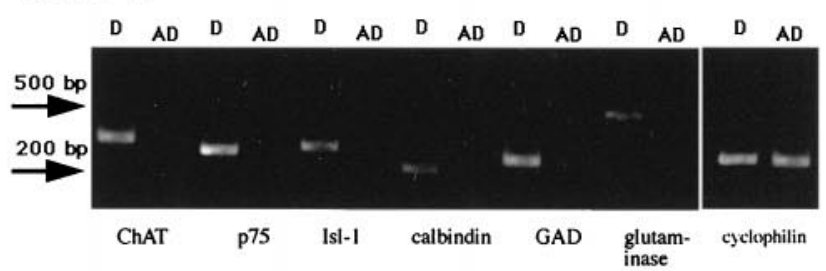

Panel 2
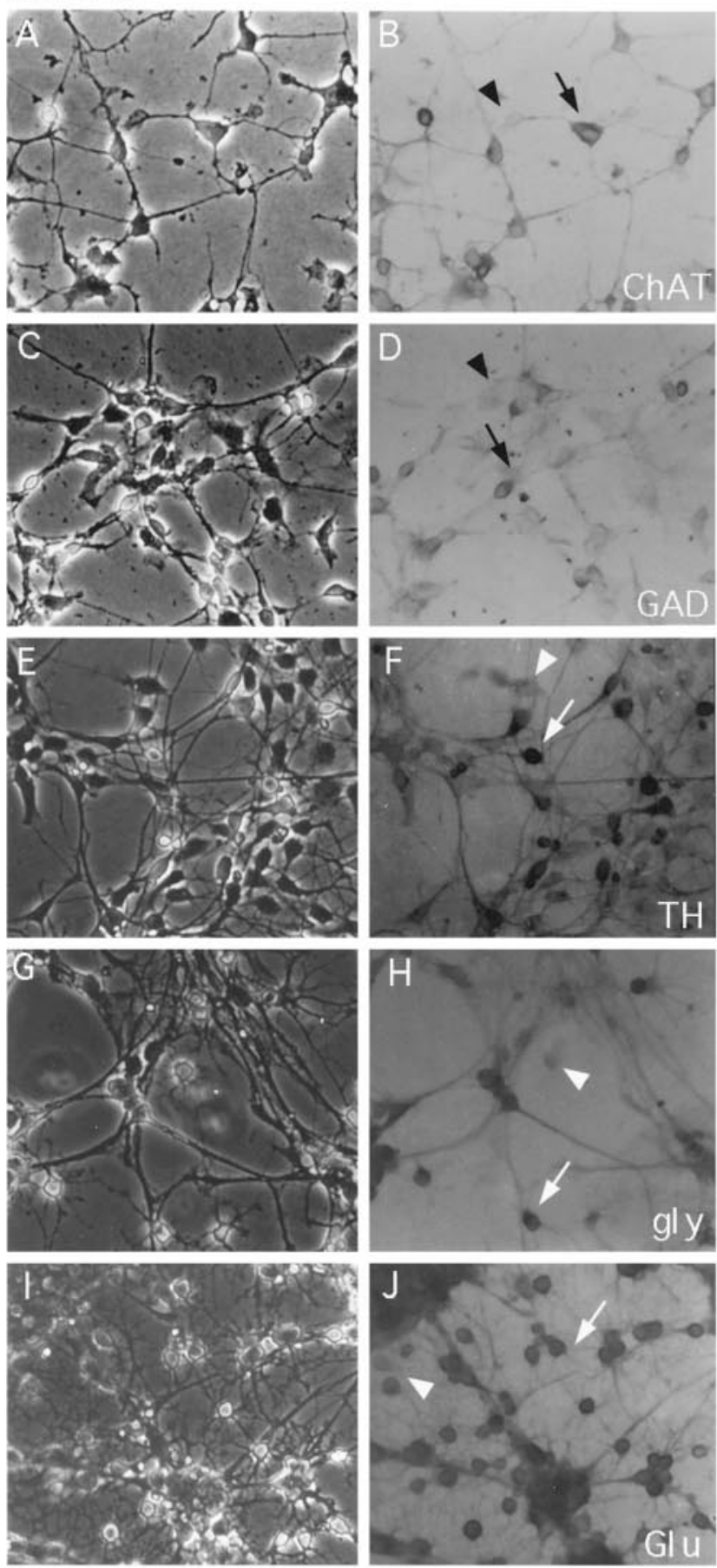

Figure 2. Numerous neuronal phenotypes can be detected by RT-PCR and antibody staining in differentiated but not acutely dissociated $\mathrm{E}-N C A M^{+}$cells. E-NCAM ${ }^{+}$cells were isolated by immunopanning, cells (Fig. 3), suggesting that more of the differentiated cells were electrically competent than were the acutely dissociated cells.

Thus, the contrast between various properties of acutely dissociated E-NCAM ${ }^{+}$cells and fully differentiated E-NCAM ${ }^{+}$cells, which is summarized in Table 2, is striking. Immature cells are mitotically active, and differentiated cells are not; immature cells do not express neuronal proteins such as NF-M, synaptophysin, or neurotransmitter synthetic enzymes, whereas all of these can be detected in differentiated cells; and acutely dissociated cells are overall less responsive than differentiated cells to neurotransmitter-induced $\mathrm{Ca}^{2+}$ responses.

\section{Individual E-NCAM ${ }^{+}$cells can generate multiple neurotransmitter phenotypes}

Our mass culture experiments show that the E-NCAM ${ }^{+}$population can generate multiple neurotransmitter phenotypes. However, there exists the possibility that individual cells are precommitted to generating specific neuronal phenotypes. To determine whether the differentiation potential of NRPs in mass culture reflected the potential of an individual NRP, we performed clonal analysis of E-NCAM ${ }^{+}$cells. E-NCAM ${ }^{+}$cells were immunoselected, plated at clonal density, and grown in FGF and NT-3, conditions that promote proliferation. Clones grew to sizes of several hundred cells after 7-10 d in culture, after which their differentiation was promoted by withdrawal of FGF and addition of RA in the medium.

Three different techniques were used to determine whether clones generated from individual NRP cells were composed of heterogeneous populations of neurons: RT-PCR, immunocytochemistry, and calcium imaging. Six clones were examined by RT-PCR analysis. Of these clones, 5/6 expressed multiple neurotransmitter phenotypes (Fig. $4 A$ ); one clone expressed all six markers tested, 3/6 expressed four markers, and 1/6 expressed three markers. Therefore, all but one clone were composed of heterogeneous populations of cells. One clone expressed detectable levels of only p75 and Isl-1 but not ChAT. This likely represents an immature clone that we had not allowed to fully differentiate. These observations that individual clones express multiple neurotransmitter synthetic enzymes or other phenotypic markers indicates that most clones were composed of a heterogeneous population.

To confirm the PCR results and to show heterogeneity at the protein level, clones were analyzed for the presence of p75 expression. No clone (0/17) consisted exclusively of p75immunoreactive cells, but all clones (17/17) contained

$\leftarrow$

plated in $35 \mathrm{~mm}$ dishes, and allowed to grow for $24 \mathrm{hr}$ (acutely dissociated), or for $10 \mathrm{~d}$ (differentiated). Cultured cells were then analyzed by RT-PCR (Panel 1) or by immunocytochemistry (Panel 2). Panel 1, RNA was isolated from acutely dissociated $(A D)$ and differentiated E-NCAM ${ }^{+}$ cells $(D)$ and assayed for the expression of ChAT, p75, Isl-1, calbindin, GAD, glutaminase, and cyclophilin (a housekeeping gene) by RT-PCR. Acutely dissociated cells did not express any of the genes tested except cyclophilin. In contrast, all markers were readily detected in differentiated cells. Thus, E-NCAM ${ }^{+}$cells begin to express neurotransmittersynthesizing enzymes or phenotypic markers after differentiation in culture. Panel 2, Differentiated E-NCAM ${ }^{+}$cells were fixed and stained with antibodies to $\operatorname{ChAT}(A, B), \operatorname{GAD}(C, D)$, TH $(E, F)$, Gly $(G, H)$, and Glu $(I, J)$. Phase $(A, C, E, G, I)$ and bright-field $(B, D, F, H, J)$ images of representative fields showing staining with each antibody are shown. Note that subsets of E-NCAM ${ }^{+}$neurons expressed each marker, the proportions of which differed between antibodies [note both the presence (arrow) and absence (arrowhead) of staining in different cells of the same population]. Objective magnification, $20 \times$. 


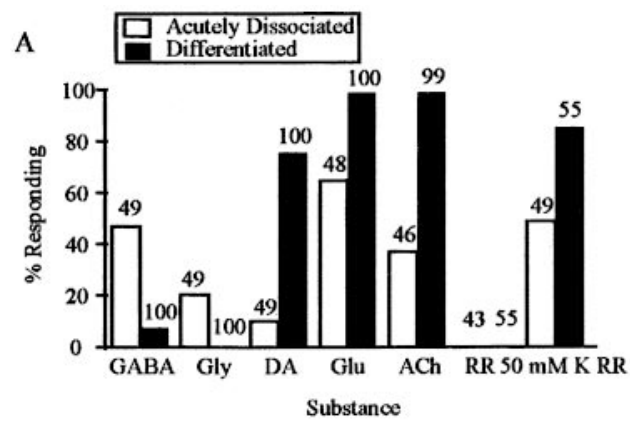

B
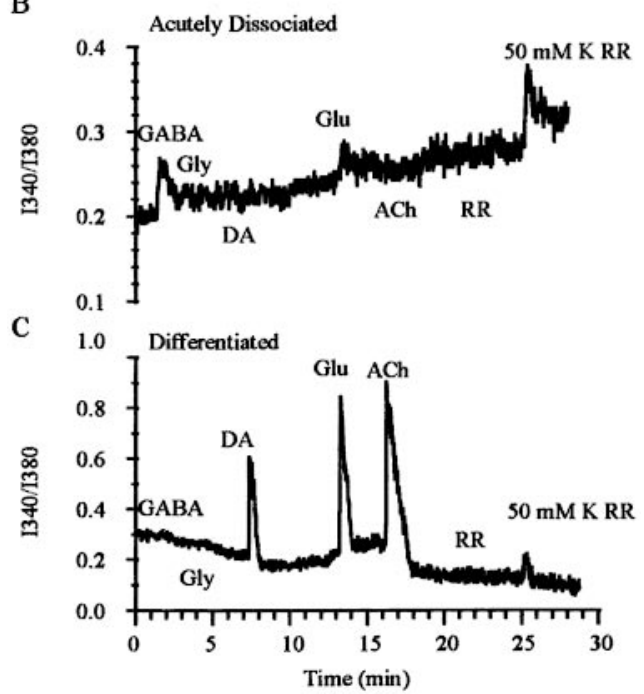

D
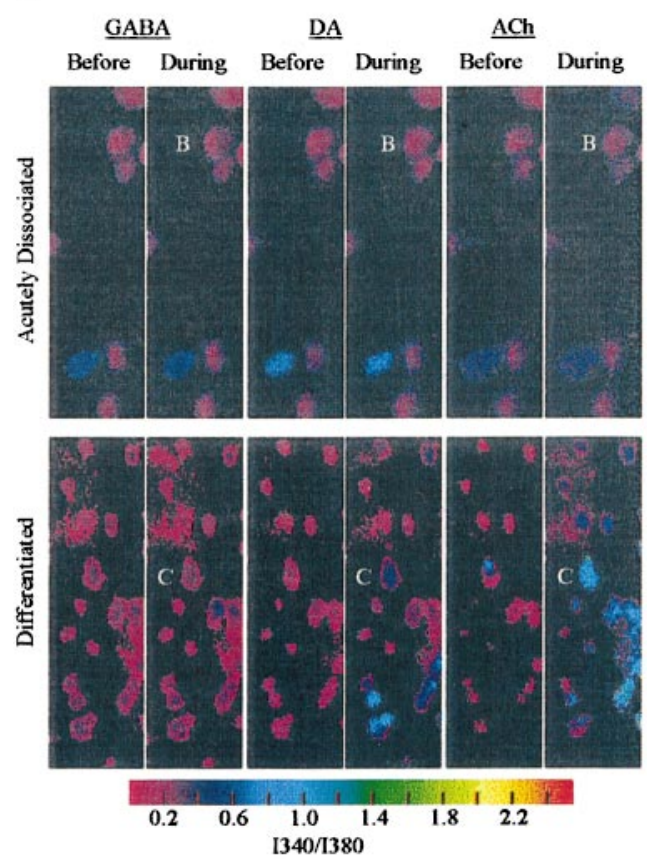

Figure 3. The neurotransmitter receptor profile of $\mathrm{E}^{-N_{C A M}}{ }^{+}$cells changes with maturation. Changes in $\left[\mathrm{Ca}^{2+}\right]_{\mathrm{i}}$ were recorded from acutely isolated and differentiated E-NCAM ${ }^{+}$cells loaded with the $\mathrm{Ca}^{2+}$ indicator dye, fura-2. $A$, The bar graph shows the percentage of E-NCAM ${ }^{+}$ cells that responded to $500 \mu \mathrm{M}$ GABA, glycine $(G l y)$, dopamine $(D A)$, glutamate $(G l u)$, acetylcholine $(A C h)$, rat Ringer's solution control $(R R)$, and elevated $\mathrm{K}^{+}\left(50 \mathrm{mM} \mathrm{K}^{+} \mathrm{RR}\right)$. The response profile changed for acutely dissociated cells (open bars) compared with differentiated cells p75-immunoreactive cells as well as other neurons. An example of a clone showing a subset of cells expressing p75 is shown in Figure $4 B$. Similarly, staining with either glutamate or glycine showed that each transmitter is expressed by only a subset of cells in the same clonal population, indicating that clones are a heterogeneous population. Figure $4 C$ shows cells from the same clone, which was split and plated into two separate dishes. One dish was stained with glutamate, and the other dish was stained with glycine. As with the E-NCAM ${ }^{+}$cells in mass culture, nearly $100 \%$ of the clonal cells were immunoreactive for glutamate, and a smaller percentage $(10-50 \% ; n=17)$ was immunoreactive for glycine. These results provide further evidence that E-NCAM ${ }^{+}$ cells generate multiple neuronal subtypes in culture.

Heterogeneity can be demonstrated not only by the synthesis of different neurotransmitters, but also by heterogeneity in the receptors expressed by the cells. We examined response profiles of differentiated clonal cells to application of GABA, glycine, dopamine, glutamate, acetylcholine, and $50 \mathrm{mM} \mathrm{K}^{+} \mathrm{RR}$, as evidenced by increased intracellular calcium concentrations. $\mathrm{Ca}^{2+}$ measurements were taken from as many as 113 cells from four different clones. All clones examined (four of four) displayed heterogeneity in their response profiles, which varied somewhat between individual clones (data not shown). Figure $5 A$ shows a bar graph of the percentage of cells from all four clones that responded to each of the applied neurotransmitters.

As with the mass cultures of differentiated E-NCAM ${ }^{+}$cells, high percentages of differentiated clonal cells responded to glutamate (93\%), acetylcholine (96\%), $50 \mathrm{~mm} \mathrm{~K}^{+} \mathrm{RR}(70 \%)$, and dopamine $(50 \%)$, whereas few cells responded to GABA $(27 \%)$ and glycine $(1 \%)$. Figure $5 B, C$ shows representative traces of the ratio $\left(I_{340} / I_{380}\right)$ of $\mathrm{Ca}^{2+}$ responses from two cells recorded from one clone. Images of these cells and the heterogeneity of receptor profiles within the clonal population are shown in Figure $5 D$. Of the cells shown in Figure $5 D$, one responded to dopamine (labeled $C$; trace shown in Fig. $5 C$ ), whereas a nearby cell (labeled $B$; trace shown in Fig. $5 B$ ) did not, suggesting that they expressed different receptors. This heterogeneous expression of receptors also indicates the multipotential characteristic of individual NRP cells. Thus, the maturation of clonal populations of cells closely resembles the maturation of cells in mass culture.

By multiple independent methods, our clonal analysis demonstrates the multipotential characteristic of individual NRP cells. This analysis confirms our mass culture results, which clearly define the developmental potential of the NRP cell. Although committed to generating neurons, the particular phenotypes of its progeny are dictated at some later stage in their development. Thus, we have established the existence of a neuronal precursor cell that can be purified and subsequently manipulated to define the transition between lineage-restricted neuronal precursor and differentiated neuronal progeny.

(closed bars; number of cells measured is indicated above each bar). The percentage of differentiated cells responding was significantly different from acutely isolated cells with all test substances (Student's $t$ test, $p<$ $0.0001) . B, C$, The ratio of intensity from excitation at $340 \mathrm{~nm}$ and $380 \mathrm{~nm}$ plotted over time shows relative changes in $\left[\mathrm{Ca}^{2+}\right]_{i}$ from acutely dissociated $(B)$ and differentiated cells $(C)$ in response to neurotransmitters, RR control, and $50 \mathrm{mM} \mathrm{K}^{+}$. Note the difference in scale for $B$ and $C$. $D$, Images of E-NCAM ${ }^{+}$cells during responses to neurotransmitters. The left half of each image is from before neurotransmitter application, and the right half is during the response. The traces in $B$ and $C$ were taken from the cells indicated with letters in $D$. 


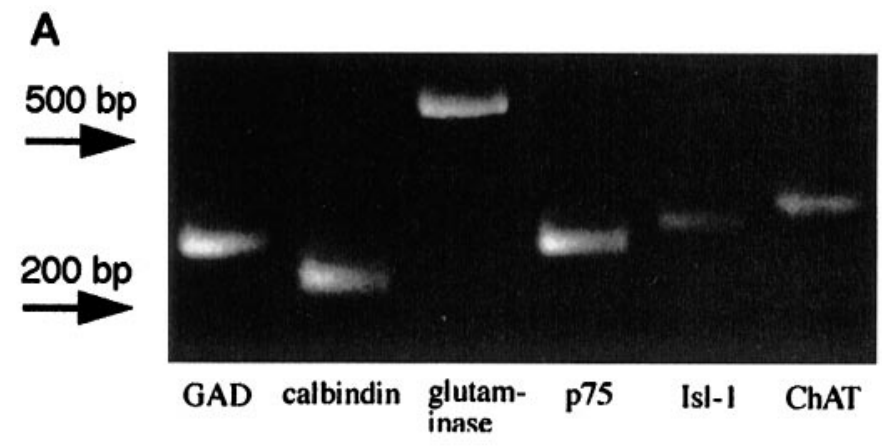

B
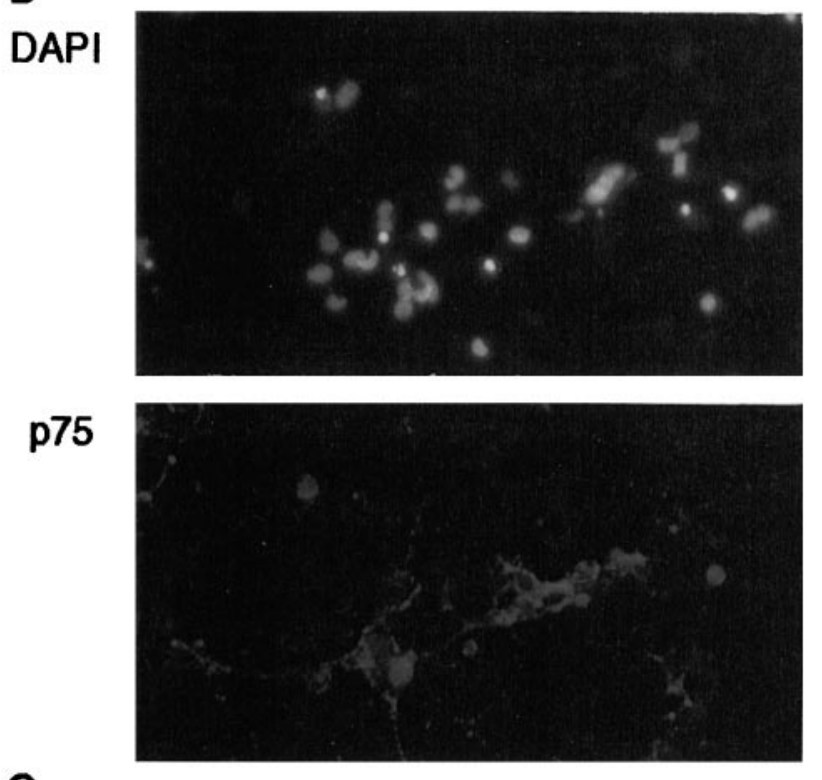

C

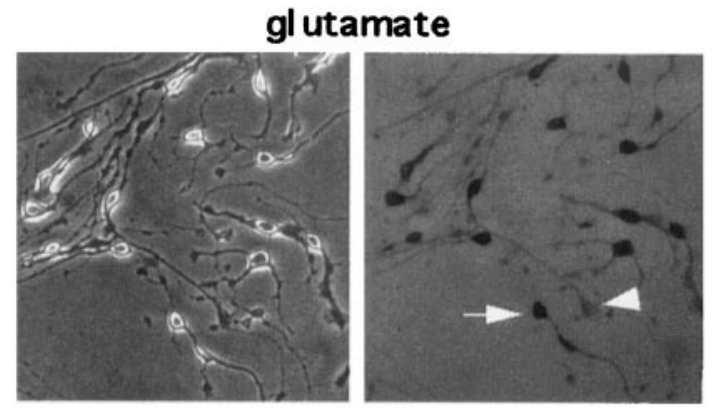

glycine
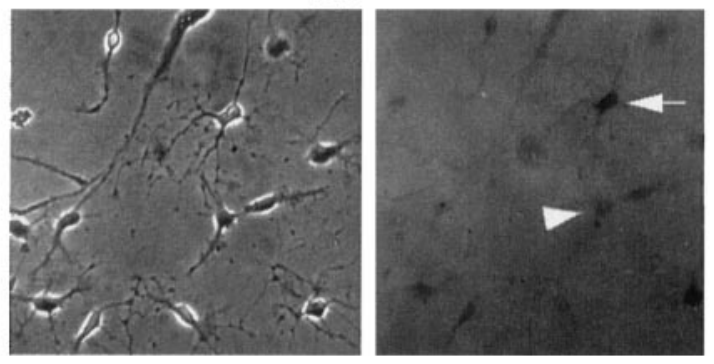

Figure 4. Individual E-NCAM ${ }^{+}$cells can generate multiple neurotransmitter phenotypes. E-NCAM ${ }^{+}$cells were plated at clonal density, and individual clones were followed and allowed to grow for a period of 7-10 d. Clones were then analyzed by RT-PCR $(A)$ or by immunocytochemistry $(B, C) . A$, RNA was isolated from individual E-NCAM ${ }^{+}$clones and assayed for the expression of GAD, calbindin, glutaminase, p75, Isl-1, and ChAT by RT-PCR. This clone expressed all of the markers tested

\section{Extracellular signals influence the fate of NRP cells}

Our results show that neuronal precursors can develop in vitro into mature neurons of multiple phenotypes in both mass and clonal cultures and that either application of RA or removal of FGF can promote differentiation into multiple phenotypes. In normal development, however, differentiation is spatially and temporally regulated, with motoneurons being generated ventrally and sensory neurons being generated dorsally, suggesting that specific environmental signals may bias differentiation of neuronal precursors (Ray and Gage, 1994; Richards et al., 1995). We examined the effects of two potential regulatory molecules that are expressed in the spinal cord at the time of neurogenesis and have been shown to bias cells to either dorsal (for review, see Graff, 1997) or ventral (for review, see Fietz et al., 1994) phenotypes, BMP-2/4 and Shh, respectively.

When BMP-2 was added to cultures of E-NCAM ${ }^{+}$cells, a dramatic reduction in cell division was seen. The effect of BMP-2 overrode the effect of the mitogen FGF; even in the presence of FGF, BMP-2 caused a $60 \%$ reduction in cell division (Fig. $6 K$ ). Identical effects were seen with BMP-4 (data not shown). BMP-2 was not a survival factor, because cells grown in BMP-2 alone did not survive. The decrease in mitosis was accompanied by the appearance of differentiated cells. Cell size increased and cells put out extensive processes (for example, see Fig. $6 F$ ). Cells grown in BMP-2 for $48 \mathrm{hr}$ were examined for neurotransmitter expression. Glutamatergic, GABAergic, dopaminergic, and cholinergic neurons were detected (data not shown) (Fig. 6F,I). The number of cholinergic neurons was significantly larger than in untreated controls (5-10 vs $0-1 \%$ ) (Fig. 6 , compare $F, I$ with $D, G$ ); however, there appeared to be no bias toward ventral phenotypes because the promotion of all other phenotypes was also significantly larger. Thus, BMP-2 acted as an antimitotic agent and promoted differentiation of $\mathrm{E}_{-} \mathrm{NCAM}^{+}$NRP cells but did not appear to inhibit ventral fates.

In contrast to the anti-mitotic and differentiation-promoting effect of BMP-2/4, Shh appeared to be a mitogen. The mitotic effect of Shh at $100 \mathrm{ng} / \mathrm{ml}$ (the maximal response) was threefold over controls but was less than the effect of FGF at $10 \mathrm{ng} / \mathrm{ml}$ (Fig. $6 J$ ). Experiments with Shh were performed in the presence of NT-3, which acts as a survival agent (for review, see Barde, 1994), and not as a mitogen, because Shh itself did not appear to be a survival factor for E-NCAM ${ }^{+}$cells; E-NCAM ${ }^{+}$cells grown in Shh alone did not survive. The effect of Shh on mitosis was only apparent after $2 \mathrm{~d}$ of exposure and was maintained over the $5 \mathrm{~d}$ of the assay.

To confirm that the effect on mitosis was caused by Shh, we obtained an anti-Shh hybridoma supernatant from DSHB and tested it in explant cultures to determine the concentration required to block motoneuron generation in explant cultures. A concentration of $50 \mu \mathrm{l} / \mathrm{ml}$ of supernatant was sufficient to completely block the generation of p75-immunoreactive motoneurons

$B, \mathrm{E}^{-N_{C A M}}{ }^{+}$clones were immunostained with $\mathrm{p} 75$, a marker for motoneurons (see Results) and counterstained with DAPI to identify all cells. $B$ shows a representative clone in which a subset of cells were immunoreactive for $\mathrm{p} 75$, demonstrating the heterogeneity of the progeny of a single $\mathrm{E}_{-} \mathrm{NCAM}^{+}$cell. $C$, A representative $\mathrm{E}-\mathrm{NCAM}^{+}$clone that was split into two different dishes. One dish was stained with glutamate and the other with glycine. Note that although the majority of progeny from a single progenitor are immunoreactive for glutamate, significantly less are immunoreactive for glycine, indicating a heterogeneous clonal population. Objective magnification, $20 \times$. 
A

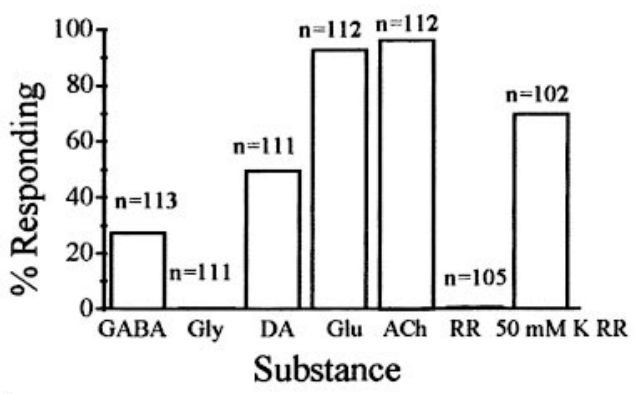

B

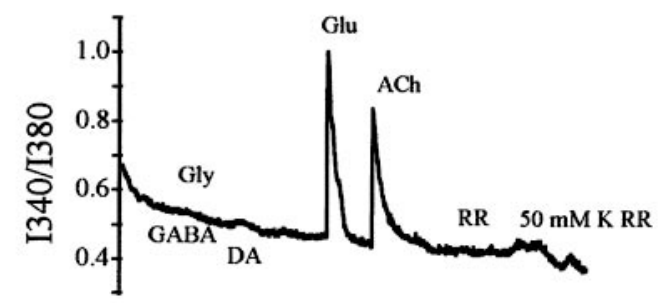

$\mathrm{C}$

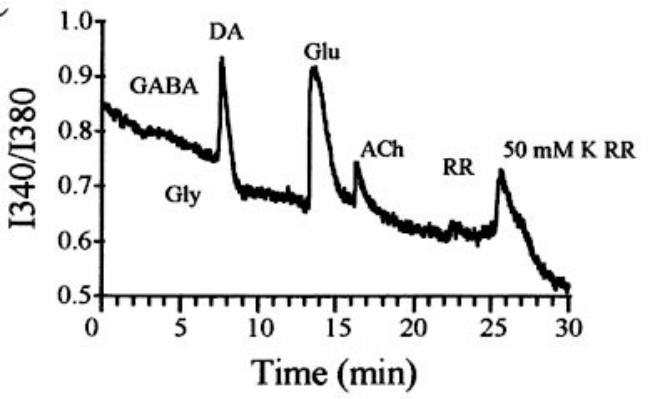

D

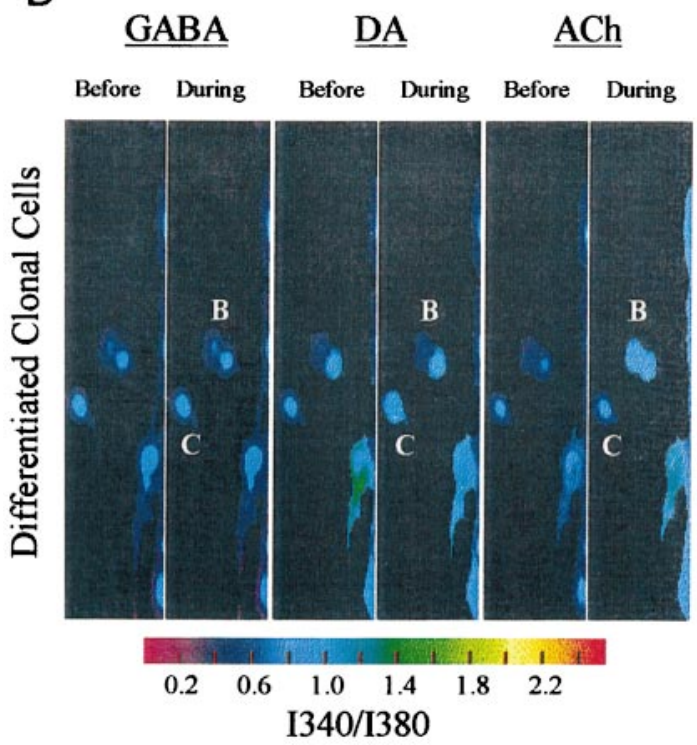

Figure 5. Individual E-NCAM ${ }^{+}$cells respond to multiple neurotransmitters. $\mathrm{Ca}^{2+}$ imaging using fura-2 showed that clonal cells generated from individual E-NCAM ${ }^{+}$neuroblasts were capable of expressing different neurotransmitter receptors. $A$, The bar graph shows the percentage of differentiated clonal cells that responded to $500 \mu \mathrm{M}$ GABA, glycine $(G l y)$, dopamine $(D A)$, glutamate $(G l u)$, acetylcholine $(A C h)$, rat Ringer's control $(R R)$, and $50 \mathrm{mM} \mathrm{K}^{+} . B, C$, The ratio of intensity from excitation at $340 \mathrm{~nm}$ and $380 \mathrm{~nm}$ plotted over time shows relative changes in $\left[\mathrm{Ca}^{2+}\right]_{\mathrm{i}}$ from two cells differentiated from one clone in response to neurotrans- (data not shown). The same concentration of Shh neutralizing antibody also completely blocked the effect of Shh on mitosis. In contrast, a control hybridoma supernatant had no inhibitory effect on Shh-induced mitosis (Fig. 7A).

To demonstrate that the observed effects of Shh on mitosis were caused by signaling through the patched-smoothened receptor complex, we examined expression of patched $(p t c)$ and smoothened (smo) in dissociated E-NCAM ${ }^{+}$cells. As can be seen in Figure $7 B$, both patched and smoothened were readily detected, indicating that the receptors are expressed by E-NCAM ${ }^{+}$ cells. Patched protein is thought to be downregulated after binding Shh, whereas ptc message is upregulated. We therefore compared the expression levels of ptc mRNA from Shh and control treated as E-NCAM ${ }^{+}$cells. E-NCAM ${ }^{+}$cells were grown alone, or in the presence of Shh (as described Materials and Methods) for $5 \mathrm{~d}$ and were harvested for RNA isolation and cDNA synthesis. Relative levels of $p t c$ expression from each population were estimated and compared by using cyclophilin/ptc ratios (as described in Materials and Methods). Results from three independent experiments indicate that Shh significantly upregulates the message for ptc $(1.48 \pm 0.18$ SEM; control $=1.00)$. Thus, Shh directly acts on $\mathrm{E}_{-} \mathrm{NCAM}^{+}$cells to regulate cell proliferation via activation of the Patched signaling pathway.

Although Shh had an obvious effect on mitosis, it had no apparent effect on p75 or ChAT expression in dissociated cultures of E-NCAM ${ }^{+}$cells (Fig. 6E,F). No cholinergic differentiation was apparent at any dose of Shh tested, and differentiation of glutaminergic or GABAergic phenotypes was not observed (data not shown). The failure to see cholinergic neurons was not caused by an inability of the E-NCAM ${ }^{+}$cells to differentiate into p75- or ChAT-positive cells, because sister cultures readily differentiated into ChAT- and p75-immunoreactive cells when treated with a differentiation agent such as BMP-2 (Fig. 6F,I) or RA (data not shown). Thus, E-NCAM ${ }^{+}$cells in dissociated culture respond to Shh by increasing cell division and by an inhibition of differentiation, in contrast to the response observed in explant cultures (our results) (Ericson et al., 1996).

Our results indicate that the extracellular signaling molecules Shh and BMP-2 modulate the phenotypic differentiation of E-NCAM ${ }^{+}$cells. BMP-2 inhibits cell proliferation and promotes differentiation and does not inhibit the differentiation of ventral phenotypes. In contrast, Shh promotes proliferation and inhibits the differentiation of any neuronal phenotypes, including p75and ChAT-immunoreactive neurons.

\section{DISCUSSION}

The data presented here demonstrate that individual, dividing E-NCAM ${ }^{+}$NRPs have the potential to generate multiple types of mature neurons that synthesize and respond to multiple neurotransmitters, including dopamine, acetylcholine, GABA, and glycine. NRP cells progress toward maturity with changes in mitotic activity, neurotransmitter response profile, and the expression of cell-type and stage-specific markers, such as neurotransmitters or their synthetic enzymes, synaptophysin, and NF-M. Finally, we report that differentiation of NRP cells can be modulated by Shh and BMP-2.

$\leftarrow$

mitters RR control and $50 \mathrm{~mm} \mathrm{~K}^{+}$. $D$, Shown are images of differentiated cells from one clone before and during responses to neurotransmitters RR control and $50 \mathrm{mM} \mathrm{K}^{+}$. The letters indicate the cells used for the traces in $B$ and $C$. 

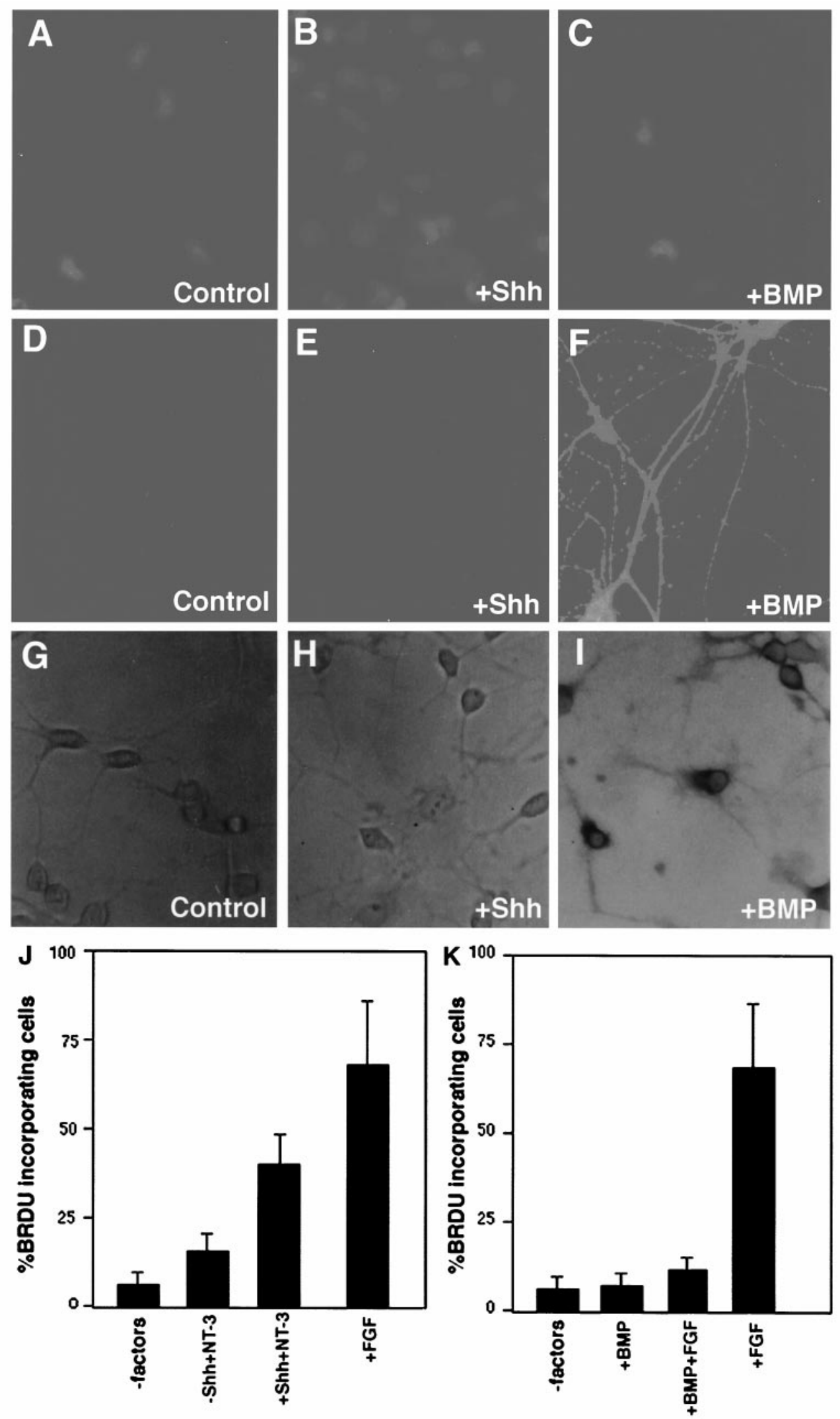

Figure 6. Shh acts on E-NCAM ${ }^{+}$neuroblasts to promote cell division, whereas BMP-2 acts on E-NCAM ${ }^{+}$neuroblasts to promote differentiation. E-NCAM ${ }^{+}$cells were isolated and grown in NEP basal medium supplemented with FGF and NT-3 $(A, D, G)$ with the addition of Shh $(100 \mathrm{ng} / \mathrm{ml})(B, E, H)$ or BMP-2 (10 ng/ ml) $(C, F, I)$. After $5 \mathrm{~d}$ in culture $(48 \mathrm{hr}$ for BMP-2), cultures were fixed, and cell division $(A, B, C), \mathrm{p} 75$ immunoreactivity $(D, E, F)$, and ChAT expression $(G, H, I)$ were compared. Comparison of cell division by BRDU incorporation showed that Shh promoted proliferation, whereas BMP-2 inhibited proliferation (compare $A, B$, and $C$ ). In contrast to the effect of Shh on proliferation, no detectable p75or ChAT-immunoreactive cells ( $E$ and $H$, respectively) were seen after Shh treatment for $5 \mathrm{~d}$. In contrast, BMP-2 treatment for $48 \mathrm{hr}$ allowed differentiation of large numbers of p75- and ChATimmunoreactive cells ( $F$ and $I$, respectively). $J$ and $K$ quantify the effect of Shh and BMP-2 on cell division. Cells were pulselabeled with BRDU for the last $24 \mathrm{hr}$ in culture, and the number of BRDUincorporating cells was counted. Sh $+N T-3$ caused a threefold increase in BRDU incorporation when compared with control conditions in which cells were treated with NT-3 alone. The effect of Shh was not as dramatic as that of FGF. In contrast, BMP-2 caused a reduction in BRDU incorporation, and this effect of BMP-2 overrode the mitogenic effect of FGF. Objective magnification, $20 \times$.
A major finding in this study is that neuronal precursor cells can generate heterogeneous progeny: clones of mature neurons that synthesize multiple neurotransmitters and differentially respond to them. More importantly, in all clones analyzed, single precursor cells generated a heterogeneous population of mature cells as assessed by immunocytochemistry and response to neurotransmitter application. The proportion of cells that responded to any single neurotransmitter varied from clone to clone, but in 
$\mathbf{A}$
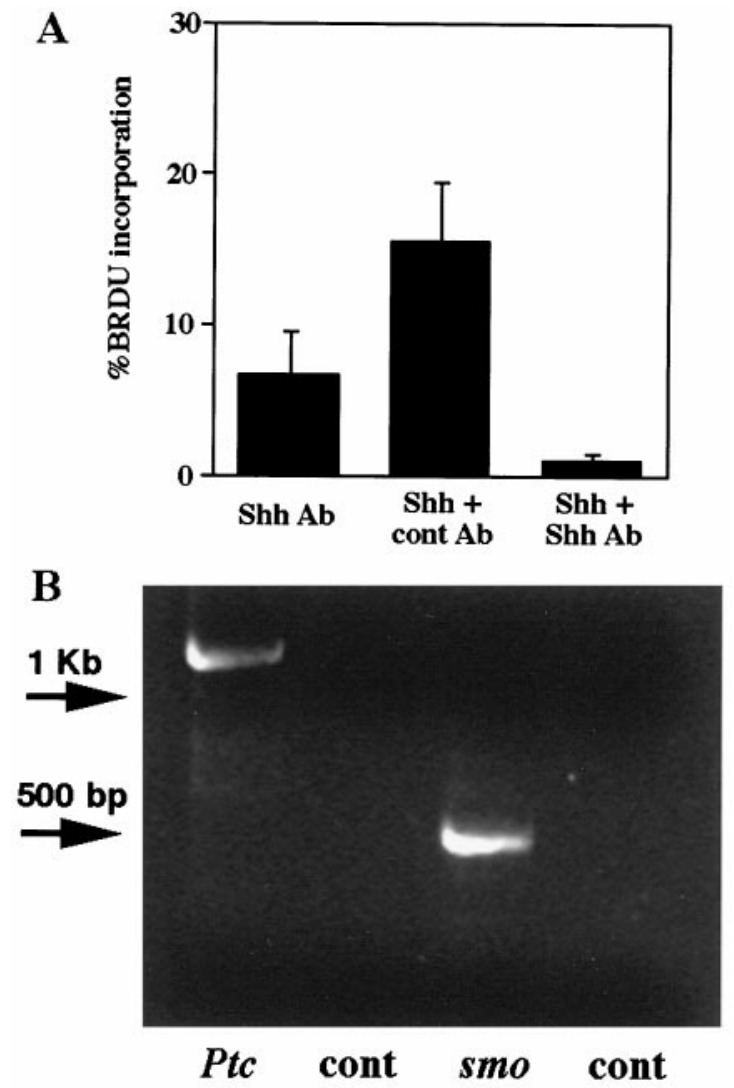

Figure 7. The mitotic effect of Shh can be blocked by neutralizing antibodies directed against Shh. E-NCAM ${ }^{+}$cells were isolated and grown in NT-3-supplemented NEP basal medium with the addition of neutralizing anti-Shh hybridoma supernatant $(50 \mu \mathrm{l} / \mathrm{ml})$, Shh $(100 \mathrm{ng} / \mathrm{ml})$ with a control hybridoma supernatant, or Shh $(100 \mathrm{ng} / \mathrm{ml})$ plus neutralizing anti-Shh hybridoma supernatant. Cells were grown for $48 \mathrm{hr}$ and pulsed with BRDU for the last $3 \mathrm{hr}$ of culture, and the number of BRDU-incorporating cells was counted. The mitotic effect of Shh on dissociated E-NCAM ${ }^{+}$cells was completely blocked in the presence of the neutralizing Shh antibody. In contrast, no effect was seen with a control (anti- $\left.\mathrm{A}_{2} \mathrm{~B}_{5}\right)$ hybridoma ( $A$, mean of 2 independent experiments). Sister plates of E-NCAM ${ }^{+}$cells were grown in culture for $48 \mathrm{hr}$, harvested, and analyzed for $p t c$ and smo expression by RT-PCR. Both $p t c$ and smo were readily detected $(B ; n=2)$.

all cases, cells that responded to either GABA, glutamate, glycine, acetylcholine, dopamine, or some combination could be identified, indicating that multiple neuronal phenotypes can arise from a single neuronal precursor. Additionally, although the NRPs were taken from the developing spinal cord, they were not limited in their potential to spinal cord cells, because we detected a significant number of dopamine-synthesizing cells that are normally not present in the spinal cord. Our clonal data also suggest that at this stage, neuronal precursors are not committed to generating only dorsal or only ventral phenotypes, because we detected cholinergic neurons as well as other neuronal phenotypes together within the same clone. Consistent with our results are results from earlier retroviral studies showing that clones in chick spinal cord can generate motoneurons as well as other neurons even relatively late in their development (Leber et al., 1990; Leber and Sanes, 1995). Mass culture assays such as those described by Ray and Gage (1994) and Richards et al. (1995) provide additional confirmation for our observations. Taken together, these results suggest that in the spinal cord, progenitor cells have made a commitment to become neurons before becoming postmitotic and acquiring a specific neuronal phenotype.

The transition of E-NCAM ${ }^{+}$cells from immature NRPs to mature, functional neurons occurs in stages, aspects of which we have identified (summarized in Table 1). Our results suggest that immature dividing precursors express E-NCAM and MAP-2 kinase, many express $\beta$-III tubulin, and only a small subset of the cells respond to excitatory neurotransmitters. These results are consistent with the expression pattern of NF and $\beta$-III tubulin described in the developing spinal cord (Chen and Chiu, 1992), as well as the development of electrical activity described in mixed cultures [Walton et al., 1993 (for review, see Spitzer, 1991)]. Of importance to note was our observation that responses to GABA and glycine by immature cells were depolarizing. Although depolarizing responses are not surprising for $\mathrm{ACh}$, dopamine, and glutamate application, the depolarizing responses to GABA and glycine are different from what might be expected for transmitters that play an inhibitory role in the mature nervous system. Nevertheless, similar depolarizing responses to both GABA and glycine have been described in embryonic spinal cord cultures (Fulton et al., 1980; Takahashi, 1984; Jahr and Yoshioka, 1986; for review see Cherubini et al., 1991). Depolarizing responses generally undergo reversal in cultures from early postnatal animals (Ben-Ari et al., 1989). We noted that mature differentiated E-NCAM ${ }^{+}$cells did not show a depolarizing response to GABA or glycine, despite the expression of their receptors, suggesting that a similar maturation had occurred in culture. These results suggest that $\mathrm{E}_{-} \mathrm{NCAM}^{+}$cells mature in culture and that this maturation mirrors many aspects of the maturation described for in vivo development of the spinal cord. The ability to analyze stages of normal development in purified populations of cells will allow for a more detailed dissection of the coordinate acquisition of maturation markers.

Our present results show that BMP-2 acts to promote neuronal differentiation from neuronal-restricted precursors. This effect is likely stage specific and direct (i.e., BMP-2 is not inducing the release of other factors from non-neuronal cells) because we used purified populations of NRP cells. We have shown previously that BMP-2 acts on NEP cells, the immediate precursors of NRP cells, to generate neural crest derivatives (Mujtaba et al., 1998). Furthermore, we and other groups have shown that BMP-2 can act on glial precursors to promote astrocytic differentiation (D’Alessandro et al., 1994; Gross et al., 1996; Mabie et al., 1997; and our unpublished results). These results illustrate the importance of examining the role of individual factors on purified cell populations at specific stages in development. The specific effect of BMP-2 on cultured cells will depend on the age of the cultured cells and on which precursor cells are present in a mixed population of cells. The specific mechanism (or mechanisms) that underlies the differential response of a precursor to BMP-2 remains to be determined.

Previous studies have shown that several members of the BMP family, including BMP-4, can promote dorsal phenotypes in explant cultures of chick spinal cord (Liem et al., 1995, 1997). Our results show that in dissociated culture there appears to be no inhibition of ventral phenotypes or a bias toward dorsal phenotypes. Rather, BMP-2/4 appeared to nonspecifically promote differentiation. These results are consistent with dorsal notochord transplant experiments (Placzek et al., 1990; Yamada et al., 1991, 1993), and ectopic Shh application experiments (Echelard et al., 1993; Roelink et al., 1994) in vivo showing that even in the 
presence of endogenous BMP-2, ventral phenotypes are readily generated, suggesting that BMP-2 does not inhibit ventralization in vivo.

Our results analyzing the effect of Shh on E-NCAM ${ }^{+}$precursor cells indicate that it acts primarily as a mitogen and does not promote cholinergic neuronal differentiation at this stage of development. The mitotic effect of Shh was not unexpected, because Shh has been shown to be a mitogen in various assays. For example, Shh has been shown to promote the proliferation of retinal precursor cells (Jensen and Wallace, 1997) and mouse sclerotome cells (Fan et al., 1995). Similarly, application of Shh to CNS stem-like cells (Flax et al., 1997), as well as to human lung squamous carcinoma cells (Fujita et al., 1997), also stimulates cell proliferation. Our results suggest that, as in other regions, one function of Shh in the spinal cord may be to promote cell division. However, our failure to see motoneuron differentiation was somewhat unexpected, because motoneuron differentiation in response to Shh application has been shown in explant cultures (Echelard et al., 1993; Roelink et al., 1994). Absence of motoneuron differentiation is not caused by an absence of the receptor, because both patched and smoothened are expressed by these cells. It also appears unlikely that an insufficient concentration of Shh was used, because even doses as high as $500 \mathrm{ng} / \mathrm{ml}$ did not show any motoneuron differentiation (see Results) (our unpublished observations). Much lower doses of Shh than the $100 \mathrm{ng} / \mathrm{ml}$ used here will readily promote generation of Islet-1/ChATimmunoreactive motoneurons in explant cultures over the same time period (Echelard et al., 1993; Roelink et al., 1994). The absence of cholinergic differentiation in our cultures cannot be attributed to the time period of the assay, because we did not see any appreciable motoneuron differentiation even after prolonged exposure to Shh. Furthermore, E-NCAM ${ }^{+}$cells readily differentiated into motoneurons $48 \mathrm{hr}$ after exposure to RA or BMP-2, indicating that the failure to see motoneuron differentiation is likely attributable to the mitogenic effect of Shh.

Previous studies suggest possible explanations for our results. Two periods of Shh signaling have been shown to be required for motoneuron specification (Ericson et al., 1996): an early period, during which Shh may convert NEP cells into ventralized precursors, and a late period, during which Shh may drive the differentiation of ventralized progenitors into motoneurons. We may be seeing the effect of only the early period of Shh application. Alternatively, it has recently been shown that vitronectin is required for motoneuron generation in the presence of Shh, but that vitronectin is not required for the patterning effects of Shh (Martinez-Morales et al., 1997). Perhaps sufficient vitronectin is not present in our relatively low-density cultures. Further experiments will be necessary to clarify our finding that Shh did not promote motoneuron differentiation in dissociated cultures. Nevertheless, our results clearly show that Shh acts at the stage of neuronal precursors to regulate their proliferation, and that E-NCAM ${ }^{+}$cultures may provide a ready assay to dissect out the role of Shh in regulating motoneuron differentiation.

In summary, we have shown that E-NCAM immunoreactivity identifies a self-renewing, NRP cell that can generate multiple neuronal phenotypes, revealing that lineage commitment to the neuronal cell type precedes its specific phenotypic commitment. In addition, this cell is amenable to perturbation by extracellular factors, allowing the processes of lineage restriction and neuronal differentiation to be characterized in detail.

\section{REFERENCES}

Abney ER, Bartlett PF, Raff MC (1981) Astrocytes, ependymal cells and oligodendrocytes develop on schedule in dissociated cell cultures of embryonic rat brain. Dev Biol 83:301-310.

Barde YA (1994) Neurotrophins: a family of proteins supporting the survival of neurons. Prog Clin Biol Res 390:45-56.

Batini C (1990) Cerebellar localization and colocalization of GABA and calcium binding protein- D28K. Arch Ital Biol 128:127-149.

Ben-Ari Y, Cherubini E, Corradetti R, Gaiarsa JL (1989) Giant synaptic potentials in immature rat CA3 hippocampal neurones. J Physiol (Lond) 416:303-325.

Berger T, Schwarz C, Kraushaar U, Monyer H (1998) Dentate gyrus basket cell $\mathrm{GABA}_{\mathrm{A}}$ receptors are blocked by $\mathrm{Zn}^{2+}$ via changes of their desensitization kinetics: an in situ patch-clamp and single-cell PCR study. J Neurosci 18:2437-2448.

Bottenstein JE, Sato G (1979) Growth of a rat neuroblastoma cell line in serum free supplemented medium. Proc Natl Acad Sci USA 76:514-517.

Cattaneo E, McKay R (1990) Proliferation and differentiation of neuronal stem cells regulated by nerve growth factor. Nature 347:762-765.

Chen EW, Chiu AY (1992) Early stages in the development of spinal motor neurons. J Comp Neurol 320:291-303.

Cherubini E, Gaiarsa JL, Ben-Ari Y (1991) GABA: an excitatory transmitter in early postnatal life. Trends Neurosci 14:515-519.

Dahlstrand J, Lardelli M, Lendahl U (1995) Nestin mRNA expression correlates with the central nervous system progenitor state in many, but not all regions of the developing nervous system. Dev Brain Res 84:109-129.

D’Alessandro JS, Yetz-Aldape J, Wang EA (1994) Bone morphogenetic proteins induce differentiation in astrocyte lineage cells. Growth Factors 11:53-69.

Desarmenien MG, Clendening B, Spitzer NC (1993) In vivo development of voltage-dependent ionic currents in embryonic Xenopus spinal neurons. J Neurosci 13:2575-2581.

Echelard Y, Epstein DJ, St-Jacques B, Shen L, Mohler J, McMahon JA, McMahon AP (1993) Sonic hedgehog, a member of a family of putative signaling molecules, is implicated in the regulation of CNS polarity. Cell 75:1417-1430.

Ericson J, Morton S, Kawakami A, Roelink H, Jessell TM (1996) Two critical periods of sonic hedgehog signaling required for the specification of motor neuron identity. Cell 87:661-673.

Fan C, Porter JA, Chiang C, Chang DT, Beachy PA, Tessier-Lavigne M (1995) Long-range sclerotome induction by sonic hedgehog: direct role of the amino-terminal cleavage product and modulation by the cyclic AMP signaling pathway. Cell 81:457-465.

Fietz MJ, Concordet J, Barbosa R, Johnson R, Krauss S, McMahon AP, Tabin C, Ingham PW (1994) The hedgehog gene family in Drosophila and vertebrate development. Development [Suppl] 43-51.

Flax JD, Yang C-H, Snyder EY (1997) Induction of proliferation of multipotent central nervous system (CNS) stem-like cell by sonic hedgehog (Shh). Soc Neurosci Abstr 23:561.1.

Frederiksen K, McKay RDG (1988) Proliferation and differentiation of rat neuroepithelial precursor cells in vivo. J Neurosci 8:1144-1151.

Fujita E, Khoroku Y, Urase K, Tsukahara T, Momoi MY, Kumagai H, Takemura T, Kuroki T, Momoi T (1997) Involvement of Sonic hedgehog in the cell growth of LK-2 cells, human lung squamous carcinoma cells. Biochem Biophys Res Commun 238:658-664.

Fujita M, Kadota T, Sato T (1996) Developmental profiles of synaptophysin in granule cells of rat cerebellum: an immunocytochemical study. J Electron Microsc (Tokyo) 45:185-194.

Fulton BP, Miledi R, Takahashi T (1980) Electrical synapses between motoneurones in the spinal cord of newborn rat. Proc R Soc Lond B Biol Sci 208:115-120.

Grabs D, Bergmann M, Schuster T, Fox PA, Brich M, Gratz M (1994) Differential expression of synaptophysin and synaptporin during preand postnatal development of the rat hippocampal network. Eur J Neurosci 6:1765-1771.

Graff JM (1997) Embryonic patterning: to BMP or not to BMP, that is the question. Cell 89:171-174.

Gross RE, Mehler MF, Mabie PC, Zang Z, Santschi L, Kessler JA (1996) Bone morphogenetic proteins promote astroglial lineage commitment by mammalian subventricular zone progenitor cells. Neuron 17:595-606.

Grynkiewicz D, Neufeld G, Schweigerer L (1985) A new generation of 
calcium indicators with greatly improved fluorescence properties. J Biol Chem 260:3440-3450.

Hamburger V (1948) The mitotic patterns in the spinal cord of the chick embryo and their relationship to the histogenetic process. J Comp Neurol 88:221-284.

Heck S, Enz R, Richter-Landsberg C, Blohm DH (1997) Expression and mRNA splicing of glycine receptor subunits and gephyrin during differentiation of P19 cells in vitro, studied by RT-PCR and immunocytochemistry. Dev Brain Res 98:211-220.

Hirano M, Goldman JE (1988) Gliogenesis in the rat spinal cord: evidence for the origin of astrocytes and oligodendrocytes from radial precursors. J Neurosci Res 21:155-167.

Jahr CE, Yoshioka K (1986) Ia afferent excitation of motoneurones in the in vitro new-born rat spinal cord is selectively antagonized by kynurenate. J Physiol (Lond) 370:515-530.

Jensen AM, Wallace VA (1997) Expression of Sonic hedgehog and its putative role as a precursor cell mitogen in the developing mouse retina. Development 124:363-371.

Kalyani A, Hobson K, Rao MS (1997) Neuroepithelial stem cells from the embryonic spinal cord: isolation, characterization and clonal analysis. Dev Biol 186:202-223.

Leber SM, Sanes JR (1995) Migratory paths of neurons and glia in the embryonic chick spinal cord. J Neurosci 15:1236-1248.

Leber SM, Breedlove SM, Sanes JR (1990) Lineage, arrangement, and death of clonally related motoneurons in chick spinal cord. J Neurosci 10:1688-1697.

Lendahl U, Zimmerman LB, McKay RD (1990) CNS stem cells express a new class of intermediate filament protein. Cell 60:585-595.

Liem KF, Tremml G, Roelink H, Jessell TM (1995) Dorsal differentiation of neural plate cell induced by BMP-mediated signals from epidermal ectoderm. Cell 82:969-979.

Liem KF, Tremml G, Jessell TM (1997) A role for the roof plate and its resident TGF $\beta$-related proteins in neuronal patterning in the dorsal spinal cord. Cell 91:127-138.

Mabie PC, Mehler MF, Marmur R, Papavasiliou A, Song Q, Kessler JA (1997) Bone morphogenetic proteins induce astroglial differentiation of oligodendroglial-astroglial progenitor cells. J Neurosci 17: 4112-4120.

Martinez-Morales JR, Barbas JA, Marti E, Bovolenta P, Edgar D, Rodriguez-Tebar A (1997) Vitronectin is expressed in the ventral region of the neural tube and promotes the differentiation of motor neurons. Development 124:5139-5147.

Mayer-Proschel M, Kalyani AJ, Mujtaba T, Rao MS (1997) Isolation of lineage-restricted precursors from multipotent neuroepithelial stem cells. Neuron 19:773-785.

McKay R (1997) Stem cells in the central nervous system. Science 276:66-71.

Miller RH, David S, Patel R, Abney ER, Raff MC (1985) A quantitative immunohistochemical study of macroglial cell development in the rat optic nerve: in vivo evidence for two distinct astrocytic lineages. Dev Biol 111:35-41.

Muhr J, Jessell TM, Edlund T (1997) Assignment of early caudal identity to neural plate cells by a signal from caudal paraxial mesoderm. Neuron 19:487-502.

Mujtaba T, Mayer-Proschel M, Rao MS (1998) A common neural progenitor for the CNS and PNS. Dev Biol, in press.

Nornes HO, Das GD (1974) Temporal pattern of neurogenesis in spinal cord of rat. I. An autoradiographic study-time and sites of origin and migration settling patterns of neuroblasts. Brain Res 73:121-138.

Phelps PE, Barber RP, Vaughn JE (1988) Generation patterns of four groups of cholinergic neurons in rat cervical spinal cord: a combined tritiated thymidine autoradiographic and choline acetyltransferase immunocytochemical study. J Comp Neurol 291:9-26.

Phelps PE, Barber RP, Brennan LA, Maines VM, Salvaterra PM, Vaughn JE (1990) Embryonic development of four subsets of cholinergic neurons in rat cervical spinal cord. J Comp Neurol 291:9-26.

Placzek M, Tessier-Lavigne M, Yamada T, Jessell T, Dodd J (1990) Mesodermal control of neural cell identity: floor plate induction by the notochord. Science 250:985-988.

Rao MS, Mayer-Proschel M (1997) Glial-restricted precursors are derived from multipotent neuroepithelial stem cells. Dev Biol 188:48-63.

Rao MS, Landis SC, Patterson PH (1992) Comparison of the sweat gland neuronal differentiation factor with known cholinergic differentiation factors. Development 116:731-744.

Rao MS, Noble M, Mayer-Proschel M (1998) A tripotential glial precursor is present in the developing spinal cord. Proc Natl Acad Sci USA 95:3996-4001.

Ray J, Gage F (1994) Spinal cord neuroblasts proliferate in response to basic fibroblast growth factor. J Neurosci 14:3548-3564.

Richards LJ, Murphy M, Dutton R, Kilpatrick TJ, Puche AC, Key B, Tan SS, Talman, PS, Bartlett PF (1995) Lineage specification of neuronal precursors in the mouse spinal cord. Proc Natl Acad Sci USA 92:10079-10083.

Roelink H, Augsburger A, Heemskerk J, Korzh V, Norlin S, Ruiz i Altaba A, Tanabe Y, Placzek M, Edlund T, Jessell TM, Dodd J (1994) Floor plate and motor neuron induction by vhh-1, a vertebrate homolog of hedgehog expressed by the notochord. Cell 76:761-775.

Spitzer NC (1991) A developmental handshake: neuronal control of ionic currents and their control of neuronal differentiation. J Neurobiol 22:659-673.

Stemple DL, Mahanthappa NK (1997) Neural stem cells are blasting off. Neuron 18:1-4.

Sudhof TC (1995) The synaptic vesicle cycle: a cascade of proteinprotein interactions. Nature 375:645-653.

Takahashi T (1984) Inhibitory miniature synaptic potentials in rat motoneurones. Proc R Soc Lond B Biol Sci 221:103-109.

Tsuchida T, Ensini M, Morton SB, Baldassare M, Edlund T, Jessell TM, Pfaff SL (1994) Topographic organization of embryonic motor neurons defined by expression of LIM homeobox genes. Cell 79:957-970.

Walton MK, Schaffner AE, Barker JL (1993) Sodium channels, GABA receptors, and glutamate receptors develop sequentially on embryonic rat spinal cord cells. J Neurosci 13:2068-2084.

Williams BP, Park JK, Alberta JA, Muhlebach SG, Hwang GY, Roberts TM, Stiles CD (1997) A PDGF-regulated immediate early gene response initiates neuronal differentiation in ventricular zone progenitor cells. Neuron 18:553-562.

Wu W, Ziskind-Conhaim L, Sweet MA (1992) Early development of glycine and GABA-mediated synapses in rat spinal cord. J Neurosci 12:3935-3945.

Wysocki LJ, Sato VL (1978) "Panning" for lymphocytes: a method for cell selection. Proc Natl Acad Sci USA 75:2844-2848.

Yamada T, Placzek M, Tanaka H, Dodd J, Jessell TM (1991) Control of cell pattern in the developing nervous system: polarizing activity of the floor plate and notochord. Cell 64:635-647.

Yamada T, Pfaff SL, Edlund T, Jessell TM (1993) Control of cell pattern in the neural tube: motor neuron induction by diffusible factors from notochord and floor plate. Cell 73:673-686.

Yan Q, Johnson EJ (1988) An immunocytochemical study of the nerve growth factor receptor in developing rats. J Neurosci 8:3481-3498.

Zhang L, Spigelman I, Carlen PL (1990) Whole-cell patch study of GABAergic inhibition in CA1 neurons of immature rat hippocampal slices. Dev Brain Res 56:127-130. 